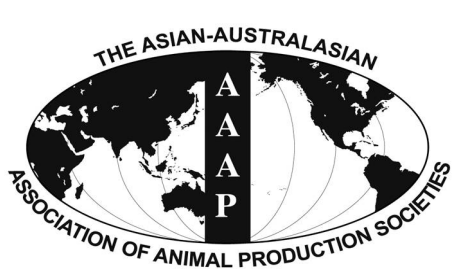

Open Access

Asian Australas. J. Anim. Sci.

Vol. 29, No. 12 : 1774-1781 December 2016

http://dx.doi.org/10.5713/ajas.15.0927

www.ajas.info

pISSN 1011-2367 elSSN 1976-5517

\title{
Antioxidant, Liver Protective and Angiotensin I-converting Enzyme Inhibitory Activities of Old Laying Hen Hydrolysate in Crab Meat Analogue
}

\author{
Sang Keun Jin, Jung Seok Choi ${ }^{1}$, Yeung Joon Choi ${ }^{2}$, Seung-Jae Lee ${ }^{3}$, Seung Yun Lee ${ }^{4}$, and Sun Jin Hur ${ }^{4, *}$ \\ Department of Animal Resources Technology, Gyeongnam National University of Science and Technology, \\ Jinju 52725, Korea
}

\begin{abstract}
The purpose of this study was to evaluate the antioxidative activities of Crab meat analogue prepared with protein hydrolysates obtained from mechanically deboned chicken meat (MDCM) from spent laying hens. 2,2-diphenyl-1-picrylhydrazyl hydrate (DPPH) radical-scavenging activity was increased by adding MDCM hydrolysates during storage, and activity correlated with the concentration of DPPH added up to 6 weeks of storage. Hydroxyl radical-scavenging activity was increased in all analogues containing MDCM hydrolysates. At 0 days of storage, angiotensin I-converting enzyme (ACE)-inhibitory activity was increased by the addition of MDCM hydrolysates. Activity did not correlate after 6 weeks of storage, in which ACE-inhibitory activity was increased with low concentrations of MDCM hydrolysates, but no ACE-inhibitory activity was observed at higher concentrations. The liverprotecting activity of crab meat analogue was shown to be around $60 \%$ of the positive control; however, it was not significantly different among the samples during storage. These results support the use of MDCM as a source of health-promoting constituents in crab meat analogue. (Key Words: Crab Meat Analogue, Mechanically Deboned Chicken Meat Hydrolysates, Antioxidative Activity, Liverprotection Effect, Antihypertension)
\end{abstract}

\section{INTRODUCTION}

In the past few decades, various meat products, such as sausages, surimi-based foods, crab meat analogue, and meat-fried fish paste, have been developed from mechanically deboned chicken meat (MDCM) of old laying hen, in an effort to introduce novel approaches towards increasing the value and utilization of these hens. The Korean meat industry has suffered problems related to old laying hen disposal, because most Korean meat consumers

\footnotetext{
* Corresponding Author: Sun Jin Hur. Tel: +82-31-670-4673, Fax:+82-31-675-3108, E-mail: hursj@cau.ac.kr.

${ }^{1}$ Swine Science and Technology Center, Gyeongnam National University of Science and Technology, Jinju 52725, Korea.

2 Department of Seafood Science and Technology, Gyeongsang National University, Tongyeong 53063, Korea.

${ }^{3}$ Natural Product Research Center, Korea Research Institute of Bioscience and Biotechnology, Jeongeup 56212, Korea.

${ }^{4}$ Department of Animal Science and Technology, Chung-Ang University, Anseong 17546, Korea.

Submitted Nov. 13, 2015; Revised Dec. 31, 2015; Accepted Feb. 19, 2016
}

have not been consuming meat from old laying hen (Jin et al., 2007). This has caused a large amount of environmental pollution and high disposal cost for carcass burning or burying (Jin et al., 2007). For these reasons, we are currently focusing on the use of MDCM in the development of functional foods, because MDCM can potentially provide economical bioactive peptides from hydrolysate proteins. Protein hydrolysates have several dietary advantages due to their high nutritional and therapeutic value (Bhaskar et al., 2007). Enzyme hydrolysis improves the nutritional and functional properties of proteins, and has been proposed for proteins from residual sources (Moure et al., 2006). In addition, protein hydrolysates from animal byproducts have been found to exhibit antioxidant activity and improved functional properties (Saiga et al., 2003; Siriangkanakun and Yongsawatdigul, 2012). In particular, peptides have been shown to exert antioxidant, antimicrobial, and antihypertensive activities (Saiga et al., 2003; Jang et al., 2008; Liu et al., 2009; Escudero et al., 2010). Arihara et al. (2001) reported that peptides possess antihypertensive activity through their ability to inhibit 
angiotensin I-converting enzyme (ACE) (Arihara et al., 2001). Many ACE-inhibitory peptides have been reported from food proteins, such as cheese whey, casein, zein, soy sauce, soybean, fish muscle sardine, and bonito (Je et al., 2005a). Thus, MDCM protein hydrolysates, which contain bioactive peptides, can be used to produce value-added meat products (Jin et al., 2010). However, the effect of MDCM hydrolysates in crab meat analogue on its bioactivities is relatively unknown. Therefore, the purpose of this study is to determine the effect of MDCM hydrolysate addition to crab meat analogue on the antioxidative, antihypertensive, and liver protective properties during storage.

\section{MATERIALS AND METHODS}

\section{Sample preparation}

Alaska Pollock, Itoyori and MDCM of old laying hen were obtained from Hansung Food Co. Ltd. (Hapduk, Korea). Three batches were collected on different days for experimental replication. The crab meat analogue samples were performed as described previously (Jin et al., 2010).

Table 1. Basic formulation of the crab meat analogue

\begin{tabular}{|c|c|c|c|c|}
\hline \multirow{2}{*}{ Ingredients $^{1}$} & \multicolumn{4}{|c|}{ Composition (\%) } \\
\hline & $\mathrm{C}$ & $\mathrm{T} 1$ & $\mathrm{~T} 2$ & T3 \\
\hline Itoyori & 40 & 40 & 40 & 40 \\
\hline MDCM hydrolysates & - & 0.50 & 1.00 & 1.50 \\
\hline Wheat starch & 17.57 & 17.57 & 17.57 & 17.57 \\
\hline Salt & 1.40 & 1.40 & 1.40 & 1.40 \\
\hline Sugar & 0.89 & 0.89 & 0.89 & 0.89 \\
\hline Crab extract & 0.64 & 0.64 & 0.64 & 0.64 \\
\hline Gluten & 0.33 & 0.33 & 0.33 & 0.33 \\
\hline Soy protein & 0.54 & 0.54 & 0.54 & 0.54 \\
\hline Crab seasoning & 0.58 & 0.58 & 0.58 & 0.58 \\
\hline L-monosodium glutamate & 0.45 & 0.45 & 0.45 & 0.45 \\
\hline Soybean oil & 0.51 & 0.51 & 0.51 & 0.51 \\
\hline Calcium carbonate & 0.42 & 0.42 & 0.42 & 0.42 \\
\hline Egg albumin & 0.13 & 0.13 & 0.13 & 0.13 \\
\hline Carrageenan & 0.16 & 0.16 & 0.16 & 0.16 \\
\hline Crab flavor & 0.10 & 0.10 & 0.10 & 0.10 \\
\hline Crab meat extract & 0.17 & 0.17 & 0.17 & 0.17 \\
\hline Red colored distilled water & 0.09 & 0.09 & 0.09 & 0.09 \\
\hline $\mathrm{K} 10 \mathrm{~B}$ & 0.08 & 0.08 & 0.08 & 0.08 \\
\hline Glycine & 0.16 & 0.16 & 0.16 & 0.16 \\
\hline Glucono delta lactone & 0.20 & 0.20 & 0.20 & 0.20 \\
\hline Phosphate & 0.20 & 0.20 & 0.20 & 0.20 \\
\hline Water & 35.38 & 34.88 & 34.38 & 33.88 \\
\hline Total & 100 & 100 & 100 & 100 \\
\hline
\end{tabular}

To make a crab meat analogue was diced into approximately 1-cm cubes, and ground through a 3-mmdiameter orifice using a mincer. Minced samples were homogenized using a Polytron homogenizer (IKA Labortechnik T25-B, Selangor, Malaysia) with distilled water at $15,000 \mathrm{rpm}$ for $30 \mathrm{~s}$. The slurry was filtered through a $1-\mathrm{mm}$-mesh metal screen to remove connective tissues. The filtrate was centrifuged at $10,000 \times \mathrm{g}$ for $25 \mathrm{~min}$ and the supernatant containing fat and water-soluble proteins was discarded. The resulting sediment was used for crab analogue manufacture. The crab meat analogue divided into three groups: $\mathrm{C}$ (commercial crab meat analogue), T1 (containing $0.5 \%$ MDCM hydrolysates), T2 (containing 1\% MDCM hydrolysates), and T3 (containing 1.5\% MDCM hydrolysates). The ingredient composition of the crab meat analogue is presented in Table 1 . The process of crab meat analogue preparation is shown as a flowchart in Figure 1 and 2.

For enzymatic hydrolysis, the commercial proteases Alcalase $2.4 \mathrm{~L}$ (2.4 AU/g), Flavourzyme $500 \mathrm{mg}$ (500 LAPU/g), Neutrase 0.8 L (0.8 AU/g), and Protamex $1.5 \mathrm{mg}$

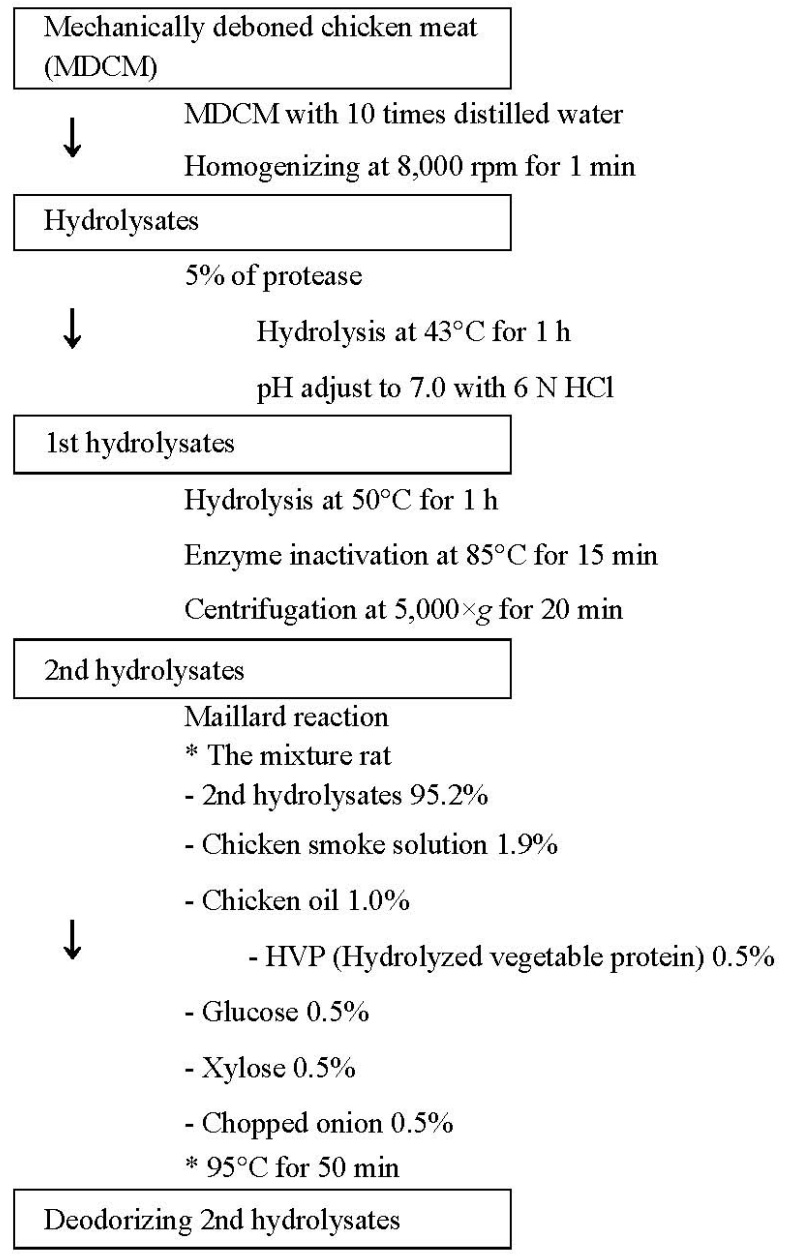

Figure 1. Manufacturing process of the mechanically deboned chicken meat hydrolysate. 


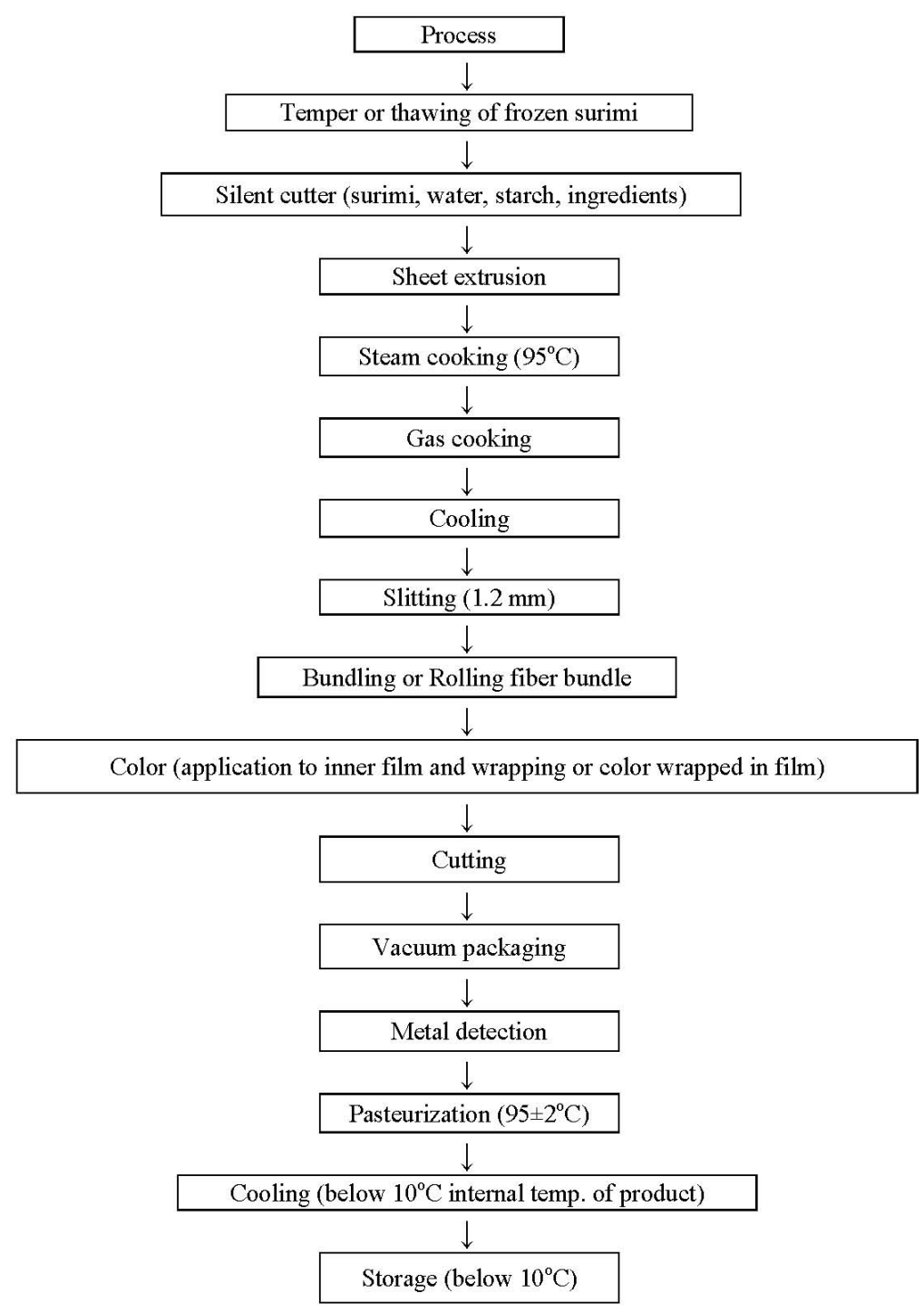

Figure 2. Manufacturing process of the crab meat analogue with mechanically deboned chicken meat hydrolysates.

(1.5 AU/g) (Novo Nordisk, Bioindustrials, Inc., Bagsværd, Denmark) were used. Pepsin (570 mg solid) and trypsin $(12,800 \mathrm{mg}$ solid) were purchased from Sigma-Aldrich Corporation (St. Louis, MO, USA). A sample (250 g) of MDCM was minced and homogenized in $250 \mathrm{~mL}$ distilled water using a Polytron homogenizer (T25-B, IKA Labortechnik, Staufen, Germany) at 8,000 rpm for $1 \mathrm{~min}$. The mixture was heated, and the $\mathrm{pH}$ was adjusted for proteases [Alcalase $\left(55^{\circ} \mathrm{C}, \mathrm{pH} 7.0\right)$, Flavourzyme $\left(50^{\circ} \mathrm{C}, \mathrm{pH}\right.$ 7.0), Neutrase $\left(50^{\circ} \mathrm{C}, \mathrm{pH} 6.0\right)$, Protamex $\left(40^{\circ} \mathrm{C}, \mathrm{pH} 7.0\right)$, pepsin $\left(37^{\circ} \mathrm{C}, \mathrm{pH} 3.0\right)$, and trypsin $\left(37^{\circ} \mathrm{C}, \mathrm{pH} 8.0\right)$ ] (Lee et al., 2010). The enzyme was added $(1 \mathrm{~g}$ enzyme $/ 100 \mathrm{~g}$ of protein) to the mixture and hydrolyzed for $0.5,1,1.5,2,4$, and $6 \mathrm{~h}$. After $6 \mathrm{~h}$, the hydrolytic process was terminated by heating the mixture up to $100^{\circ} \mathrm{C}$ and maintaining this temperature for $10 \mathrm{~min}$ to ensure complete inactivation of the enzyme. The resulting slurry was centrifuged at $3,000 \times g$
(Union 5KR, Hanil, Seoul, Korea) for $20 \mathrm{~min}$. The protein hydrolysate was stored in a cold chamber at $4^{\circ} \mathrm{C}$.

\section{Determination of 2,2-diphenyl-1-picrylhydrazyl hydrate radical-scavenging activity}

The 2,2-diphenyl-1-picrylhydrazyl hydrate (DPPH) radical-scavenging activity was evaluated using the method of Brand-Williams et al. (1995) with some modifications. A solution of $6.5 \mu \mathrm{M}$ DPPH in methanol was prepared daily before measurement. The sample $(2 \mathrm{~mL})$ was mixed with 3 $\mathrm{mL}$ of the DPPH solution, and the final concentration of DPPH was $0.1 \mathrm{mM}$. The reaction mixtures were shaken vigorously and incubated in the dark for $30 \mathrm{~min}$. The blank sample contained the same amount of methanol and DPPH. The measurements were performed in triplicate, with absorbance of the solution measured at $517 \mathrm{~nm}$. The radical-scavenging activity was calculated by the formula: 
DPPH inhibition $(\%)=\left[\left(\mathrm{A}_{\mathrm{B}}-\mathrm{A}_{\mathrm{A}}\right) / \mathrm{A}_{\mathrm{B}}\right] \times 100$

Where, $A_{B}=$ absorption of the blank sample and $A_{A}=$ absorption of the tested sample.

\section{Determination of superoxide radical-scavenging activity}

The superoxide radical-scavenging activity was estimated at $25^{\circ} \mathrm{C}$ using spectrophotometric monitoring of the inhibition of pyrogallol autoxidation, as previously described by Marklund and Marklund (1974) with some modifications. This assay is dependent on the reducing activity of test compound by an $\mathrm{O}_{2}^{-}$-dependent reaction that releases chromophoric products. Pyrogallol solution $(3 \mathrm{mM})$ was added to a tube containing chicken protein hydrolysates fractions $(2.0 \mathrm{mg} / \mathrm{mL})$ previously dissolved in Tris-HCl-EDTA (ethylenediaminetetraacetic acid) buffer $(0.1 \mathrm{M}, \mathrm{pH}$ 8.0). The optical density (OD) was measured in triplicate at $320 \mathrm{~nm}$ using a spectrophotometer. The antioxidant activity was determined as the percentage of inhibiting pyrogallol autoxidation, which was calculated from the OD in the presence or absence of pyrogallol and chicken protein hydrolysates fraction.

\section{Determination of hydroxyl radical-scavenging activity}

Hydroxyl radicals were generated by the Fenton reaction, and reacted rapidly with the nitrone spin trap 5, 5dimethyl-1-pyrroline N-oxide (DMPO). The resulting DMPO-OH adduct was detectable with an electron spin resonance (ESR) spectrometer (Rosen and Rauckman, 1984). The ESR spectrum was recorded $2.5 \mathrm{~min}$ after mixing a phosphate-buffered solution $(\mathrm{pH} 7.4)$, containing $0.3 \mathrm{M}$ DMPO $(0.2 \mathrm{~mL}), 10 \mathrm{mM} \mathrm{FeSO}_{4}(0.2 \mathrm{~mL})$, and 10 $\mathrm{mM} \mathrm{H} \mathrm{O}_{2}(0.2 \mathrm{~mL})$, using an ESR spectrometer set at the following conditions: central field, $3475 \mathrm{G}$; modulation frequency, $100 \mathrm{kHz}$; microwave frequency, $9.44 \mathrm{GHz}$; modulation amplitude, $2 \mathrm{G}$; microwave power, $5 \mathrm{~mW}$; gain, $6.3 \times 10^{5}$; temperature, $298 \mathrm{~K}$.

\section{Determination of angiotensin I-converting enzyme activity}

ACE activity was determined using Hippuryl-His-Leu (HHL) with the methods reported by Janitha et al. (2002). The assay was conducted in a borate buffer $(0.1 \mathrm{M}, \mathrm{pH} 8.3)$. The assay volume consisted of $150 \mu \mathrm{L}$ of the ACE enzyme solution and $40 \mu \mathrm{L}$ of assay sample. All of the solutions were incubated for $10 \mathrm{~min}$ at $37^{\circ} \mathrm{C}$. Then, $5 \mathrm{~mL}$ of HHL $(0.3 \mathrm{M})$ and $100 \mu \mathrm{L}$ of $0.1 \mathrm{M}$ borate buffer $(\mathrm{pH} 8.3)$ were added and incubated for $30 \mathrm{~min}$. To stop ACE activity, $1 \mathrm{M}$ $\mathrm{HCl}(150 \mu \mathrm{L})$ was added. The reaction mixture obtained was used to quantitate the hippuric acid produced due to ACE activity on the substrate. High-performance liquid chromatography determination of hippuric acid content utilized a reversed-phase $\mathrm{C}_{18}$ column (Bondclone $\mathrm{C}_{18}, 10$ $\mu \mathrm{M}, 50 \times 1.0 \mathrm{~mm}$, Phenomenex Co., Torrance, CA, USA) protected by a guard column (Bondclone $\mathrm{C}_{18}, 5 \mu \mathrm{M}$, $250 \times 4.6 \mathrm{~mm}$ ). The injection volume was $20 \mu \mathrm{L}$. Elution of hippuric acid was detected by monitoring the absorbance at $228 \mathrm{~nm}$. The control reaction mixture contained $40 \mu \mathrm{L}$ of buffer instead of the assay sample. The percent inhibition of enzyme activity was calculated as follows:

$$
\begin{aligned}
& \text { ACE inhibition }(\%) \\
& =[\text { (hippuric acid of control-hippuric acid of sample }) \\
& \quad \text { /hippuric acid of control }] \times 100
\end{aligned}
$$

\section{Determination of liver-protecting activity}

Chang liver cells were grown in Dulbecco's modified Eagle medium containing $10 \%(\mathrm{v} / \mathrm{v})$ fetal bovine serum, $100 \mu \mathrm{g} / \mathrm{mL}$ penicillin/streptomycin, and $5 \% \mathrm{CO}_{2}$, at $37^{\circ} \mathrm{C}$. Cytotoxicity levels of the samples on cells were measured using the 3-(4,5-dimethylthiazol-2-yl)-2,5-diphenyltetrazolium bromide (MTT) method as described previously (Kaviarasan et al., 2007). The cells were grown in 96-well plates at a density of $5 \times 10^{3}$ cells/well. After $24 \mathrm{~h}$, cells were replaced with fresh medium and treated with different concentrations of N-alkyl (HB-COS). After $24 \mathrm{~h}$ of incubation, cells were rewashed, and $100 \mu \mathrm{L}$ of MTT (1 $\mathrm{mg} / \mathrm{mL}$ ) was added and incubated for $4 \mathrm{~h}$. Finally, $200 \mu \mathrm{L}$ of dimethyl sulfoxide was added to solubilize the formazan salt formed, and the amount of formazan salt was determined by measuring the $\mathrm{OD}$ at $540 \mathrm{~nm}$ using a GENios microplate reader (Tecan Austria GmbH, Grodig, Salzburg, Austria). Relative cell viability was calculated compared to the non-treated control group.

\section{Statistical analysis}

Statistical analyses were performed 3 times for all experimental items. The data are expressed as the mean \pm standard error of mean. For each batch, data on the DPPH radical-scavenging activity, superoxide radicalscavenging activity, hydroxyl radical-scavenging activity, ACE-inhibitory activity, and liver-protecting activity were analyzed using Student's $t$-test for paired data with Graph Pad Prism software version 4.00 (Graph Pad Software Inc., San Diego, CA, USA) was used. Significant differences $(p<0.05)$ between mean values of triplicate samples were determined for all experiments.

\section{RESULTS AND DISCUSSION}

Results of the DPPH radical-scavenging activity of crab meat analogue containing MDCM hydrolysates are shown in Table 2. DPPH radical-scavenging activity was increased with the addition of MDCM hydrolysates during storage, 
Table 2. DPPH radical-scavenging activity of crab meat analogue containing MDCM hydrolysates during storage

\begin{tabular}{lcccc}
\hline \multirow{2}{*}{ Storage } & \multicolumn{4}{c}{ Treatments $^{1}$} \\
\cline { 2 - 5 } & $\mathrm{C}$ & $\mathrm{T} 1$ & $\mathrm{~T} 2$ & $\mathrm{~T} 3$ \\
\hline 0 weeks & $1.4 \pm 0.5^{\mathrm{cA}}$ & $3.5 \pm 0.2^{\mathrm{bA}}$ & $3.1 \pm 0.2^{\mathrm{bA}}$ & $7.4 \pm 0.8^{\mathrm{aA}}$ \\
6 weeks & $0.9 \pm 0.4^{\mathrm{cB}}$ & $1.6 \pm 0.2^{\mathrm{cB}}$ & $1.8 \pm 0.3^{\mathrm{bB}}$ & $5.2 \pm 0.6^{\mathrm{aB}}$ \\
\hline
\end{tabular}

DPPH, 2,2-diphenyl-1-picrylhydrazyl hydrate; MDCM, mechanically deboned chicken meat.

${ }^{1}$ The treatments are the same as those in Table 1.

A-B Means with different superscript letters in a column within each treatment differ significantly $(\mathrm{p}<0.05)$.

${ }^{a-c}$ Means with different superscript letters in a row at storage time differ significantly $(\mathrm{p}<0.05)$

although all samples had decreased DPPH radicalscavenging activity values after 6 weeks of storage. In particular, T3, which contained 1.5\% MDCM hydrolysate, showed the highest DPPH radical-scavenging activity compared to those of the other crab meat analogue samples. Results of the superoxide radical-scavenging activity of crab meat analogue containing MDCM hydrolysates are shown in Table 3. At 0 days of storage, superoxide radicalscavenging activity was increased in $\mathrm{T} 2$ and $\mathrm{T} 3$ samples, which contained $1.0 \%$ and $1.5 \%$ MDCM hydrolysate, respectively, compared with $\mathrm{C}$ and $\mathrm{T} 1$ (0.5\% MDCM hydrolysate). However, superoxide radical-scavenging activity was shown to not exhibit consistent trends after 6 weeks of storage. Results of the hydroxyl radicalscavenging activity of crab meat analogue containing MDCM hydrolysates are shown in Table 4. Hydroxyl radical-scavenging activity was higher in all MDCM hydrolysate treatments compared to the control during storage. Moreover, hydroxyl radical-scavenging activities of $\mathrm{T} 2$ and T3 were increased after 6 weeks of storage. Results of the ACE-inhibitory activity of crab meat analogue containing MDCM hydrolysates are shown in Table 5. At 0 days of storage, ACE-inhibitory activity was increased by the addition of MDCM. However, after 6 weeks of storage, ACE-inhibitory activity was higher in $\mathrm{T} 1$ and $\mathrm{T} 2$ compared to the control sample, unlike the T3 sample (containing $1.5 \%$ MDCM hydrolysate) before storage, which had no ACE-inhibitory activity. Results of the liver-protecting

Table 3. Superoxide radical-scavenging activity of crab meat analogue containing MDCM hydrolysates during storage

\begin{tabular}{lcccc}
\hline \multirow{2}{*}{ Storage } & $\mathrm{C}$ & Treatments & \\
\cline { 2 - 5 } & $\mathrm{C} 1$ & $\mathrm{~T} 2$ & $\mathrm{~T} 3$ \\
\hline 0 weeks & $28.34 \pm 0.5^{\mathrm{cB}}$ & $29.5 \pm 0.1^{\mathrm{cB}}$ & $35.7 \pm 0.1^{\mathrm{bA}}$ & $42.1 \pm 0.2^{\mathrm{aA}}$ \\
6 weeks & $30.30 \pm 0.1^{\mathrm{bA}}$ & $45.1 \pm 0.2^{\mathrm{aA}}$ & $23.3 \pm 0.2^{\mathrm{cB}}$ & $30.4 \pm 0.1^{\mathrm{bB}}$ \\
\hline MDCM, mechanically deboned chicken meat. \\
${ }^{1}$ The treatments are the same as those in Table 1. \\
A-B Means with different superscript letters in a column within each \\
treatment differ significantly (p<0.05). \\
a-c Means with different superscript letters in a row at storage time differ \\
significantly $(\mathrm{p}<0.05)$.
\end{tabular}

Table 4. Hydroxyl radical-scavenging activity of crab meat analogue containing MDCM hydrolysates during storage

\begin{tabular}{lcccc}
\hline \multirow{2}{*}{ Storage } & \multicolumn{4}{c}{ Treatments $^{1}$} \\
\cline { 2 - 5 } & $\mathrm{C}$ & $\mathrm{T} 1$ & $\mathrm{~T} 2$ & $\mathrm{~T} 3$ \\
\hline 0 weeks & $48.3 \pm 0.1^{\mathrm{dB}}$ & $53.3 \pm 0.2^{\mathrm{b}}$ & $50.1 \pm 0.1^{\mathrm{cB}}$ & $55.1 \pm 0.1^{\mathrm{aB}}$ \\
6 weeks & $50.2 \pm 0.3^{\mathrm{dA}}$ & $53.1 \pm 0.2^{\mathrm{c}}$ & $55.2 \pm 0.1^{\mathrm{bA}}$ & $56.1 \pm 0.2^{\mathrm{aA}}$ \\
\hline
\end{tabular}

MDCM, mechanically deboned chicken meat.

${ }^{1}$ The treatments are the same as those in Table 1.

A-B Means with different superscript letters in a column within each treatment differ significantly $(\mathrm{p}<0.05)$.

${ }^{a-d}$ Means with different superscript letters in a row at storage time differ significantly $(\mathrm{p}<0.05)$.

activity of crab meat analogue containing MDCM hydrolysates are shown in Figure 3. The liver-protecting activity of crab meat analogue was shown to be around $60 \%$ of the positive control. However, liver-protecting activity was not significantly different among the sample during storage.

The results of this study showed that the addition of MDCM hydrolysates has antioxidative activity in crab meat analogue during storage. This conclusion is based on observations that DPPH, superoxide, and hydroxyl radicalscavenging activities were increased by the addition of MDCM in crab meat analogue. Possible mechanisms for antioxidative activity may be due to peptides of MDCM hydrolysate. Our previous study exhibited high antioxidative activities of MDCM hydrolysates such as DPPH, hydroxyl, and superoxide radical scavenging activities in a dose-dependent manner (data not shown). Wu et al. (2003) reported that for mackerel protein hydrolysate, porcine hemoglobin hydrolysates prepared through the hydrolysis by Alcalase, followed by Flavourzyme, exhibited high ferrous ion-chelating abilities and DPPH radicalscavenging activity. In our research, the DPPH radicalscavenging activities of the MDCM hydrolysates were similar to those reported by Wu et al. (2004). Sakanaka and Tachibana (2006) reported inhibition of the lipid oxidation values in beef homogenate by egg-yolk protein hydrolysates. Flaczyk et al. (2006) also found that hydrolysates possessed lower antioxidant activity in meatballs. In another study,

Table 5. Angiotensin I-converting enzyme (ACE) inhibitory activity of crab meat analogue containing MDCM hydrolysates during storage

\begin{tabular}{lcccc}
\hline \multirow{2}{*}{ Storage } & \multicolumn{4}{c}{ Treatments $^{1}$} \\
\cline { 2 - 5 } & $\mathrm{C}$ & $\mathrm{T} 1$ & $\mathrm{~T} 2$ & $\mathrm{~T} 3$ \\
\hline 0 weeks & $1.3 \pm 0.4^{\mathrm{c}}$ & $1.9 \pm 0.4^{\mathrm{bA}}$ & $5.7 \pm 0.5^{\mathrm{aA}}$ & $2.1 \pm 0.2^{\mathrm{b}}$ \\
6 weeks & - & $0.4 \pm 0.6^{\mathrm{B}}$ & $0.8 \pm 1.2^{\mathrm{B}}$ & -
\end{tabular}

MDCM, mechanically deboned chicken meat.

${ }^{1}$ The treatments are the same as those in Table 1.

A-B Means with different superscript letters in a column within each treatment differ significantly $(\mathrm{p}<0.05)$.

${ }^{a-c}$ Means with different superscript letters in a row at storage time differ significantly $(\mathrm{p}<0.05)$. 


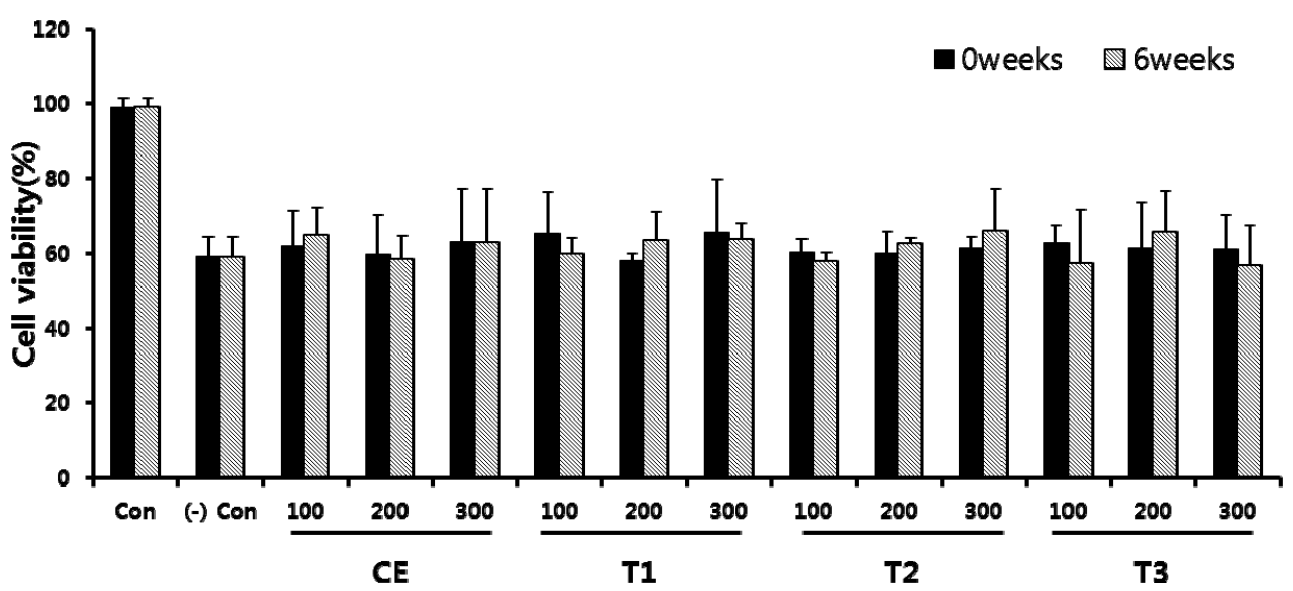

Figure 3. Liver-protecting activity of chang cells by crab meat analogue containing mechanically deboned chicken meat hydrolysates.

hydrolysates at doses ranging from $1 \%$ to $2 \%$ decreased the speed of lipid oxidation of pork patties, but their activity remained weaker than that of synthetic antioxidants (PenaRamos and Xiong, 2003). Wu et al. (2003) suggested that the antioxidant activity of peptides depends on their amino acid compositions and sequences, and that histidinecontaining peptides possess a higher activity. This activity may be attributed to the chelating and lipid radical-trapping ability of the imidazole ring (Je et al., 2005b). Presumably, peptide cleavages led to enhanced $\mathrm{Fe}^{2+}$ binding due to an increased concentration of carboxylic (COO-) and amino groups in the branches of acidic and basic amino acids, thus removing the pro-oxidative free metal ion from the hydroxyl radical system (Dong et al., 2008). Some di- and tripeptides containing aromatic amino acid residues, as well as peptides containing Cys, Pro, or His, showed a strong antioxidative effect. Qian et al. (2008) reported that alanine, valine, leucine, and proline, with non-polar aliphatic groups, have high reactivity to hydrophobic polyunsaturated fatty acids. Additionally, they showed that aromatic residues (tyrosine, histidine, tryptophan, and phenylalanine) can make reactive oxygen species (ROS) stable through direct electron transfer. Moreover, hydrogen donors, such as glycine, aspartic acid, glutamate, and tyrosine, are able to quench unpaired electrons or radicals by supporting protons (Qian et al., 2008). These are the main reasons why the addition of MDCM hydrolysate provides antioxidative activity in crab meat analogue during storage. Therefore, MDCM hydrolysates can be used as a good source of antioxidants in crab meat analogue.

ROS are unstable and react readily with other groups or substances in the body, resulting in cell or DNA damage. Indeed, liver damage can be caused by ROS, and protein hydrolysate could increase the antioxidant enzyme activity of the liver (Liu et al., 2011). Chen et al. (2007) reported that protein hydrolysate displayed noticeable inhibition of liver lipid autoxidation. Battaller and Brenner (2005) also suggested that serum levels of proteins are directly related to the hepatic fibrogenic process. However, this study showed that MDCM hydrolysate in crab meat analogue exhibits no liver-protecting activity. This result indicates that the antioxidative activity of MDCM hydrolysate does not influence liver-protecting activity. This result is not clearly understood, but it may be due to the amount of MDCM hydrolysate in crab meat analogue not sufficient for protecting the damaged liver cell.

In this study, the authors found that the addition of MDCM hydrolysate showed ACE-inhibitory activity in crab meat analogue during storage. This effect may be closely related to peptides in the MDCM hydrolysate, as peptides released from proteins have been widely studied for the control of hypertension, mostly based on their perceived activity in inhibiting ACE of the physiological blood pressure-regulating renin angiotensin system pathway (Udenigwe and Mohan, 2014). Angiotensin I circulates in the blood until its C-terminal dipeptide residue is cleaved by ACE to form an octapeptide angiotensin II, which acts as a potent vasoconstrictor (Udenigwe and Mohan, 2014). Emerging evidence indicates that bioactive peptides can also interact with renin (released by kidneys in response to low blood pressure), angiotensin system-related renin, angiotensin II receptor, the arginine-nitric oxide pathway, the endothelin system, and $\mathrm{Ca}^{2+}$ channels, which may mediate their physiological antihypertensive effects in addition to ACE inhibition (Udenigwe and Mohan, 2014). Udenigwe et al. (2012) suggested that the presence of $\mathrm{N}$ terminal aliphatic (e.g., leucine, isoleucine, valine) and Gterminal bulky (e.g., phenylalanine, tryptophan) amino acid residues contribute to higher renin-inhibitory activity of dipeptides. Thus, we assume that the inhibition of renin is one of the main reasons for the ACE-inhibitory activity of peptides of MDCM hydrolysate in crab meat analogue. Actually, ACE-inhibitory peptides have been discovered in various animal sources, such as porcine and chicken muscle. 
Saiga et al. (2003) reported that Gly-Phe-Hyp-Gly-ThrHyp-Gly-Leu-Hyp-Gly-Phe $\left(\mathrm{IC}_{50}=42 \mu \mathrm{M}\right)$ isolated from chicken breast muscle hydrolysate exhibits an ACEinhibitory effect. Arihara et al. (2001) discovered ACEinhibitory peptides, such as Met-Asn-Pro-Asn $\left(\mathrm{IC}_{50}=66.6\right.$ $\mu \mathrm{M})$, Asn-Pro-Pro $\left(\mathrm{IC}_{50}=290.5 \mu \mathrm{M}\right)$, and Thr-Asn-Pro $\left(\mathrm{IC}_{50}=207.4 \mu \mathrm{M}\right)$, in porcine myosin hydrolysate. In addition, Ahhmed et al. (2009) reported that mixing 5\% meat hydrolysate from the porcine muscle biceps femoris with the normal diet of rats resulted in apparent positive effects on a common lifestyle-related disease. Another possible mechanism for the antihypertensive activity of peptide may be through nitric oxide. Nitric oxide is a potent vasodilator and can also react with homocysteine to form Snitroso-homocysteine, which can also induce vasodilation (Perna et al., 2003). In the vascular endothelium, bradykinin mediates a signaling process that results in the activation of $\mathrm{Ca}^{2+}$ /calmodulin-dependent endothelial nitric oxide synthase, which catalyzes the conversion of arginine to nitric oxide and citrulline (Udenigwe and Mohan, 2014). Therefore, a higher level of arginine in the vascular endothelium can potentially induce vasodilation (Perna et al., 2003). Although many studies have reported ACEinhibitory peptides from various food proteins, this is the first report showing that the addition of MDCM hydrolysates inhibited ACE in crab meat analogue.

\section{CONCLUSION}

This study was carried out to determine the antioxidative activity, ACE-inhibitory activity, and liverprotecting activity of crab meat analogue containing different levels of MDCM hydrolysates obtained from old laying hen. Our results demonstrate that the addition of MDCM hydrolysates in crab meat analogue resulted in increased antioxidative activity. Moreover, ACE-inhibitory activity and liver-protecting activity were increased by the addition of MDCM hydrolysates to crab meat analogue during storage. Our findings suggest that MDCM hydrolysates can be used as a good source of healthpromoting constituents in functional foods with crab meat analogue. Moreover, crab meat analogue manufactured by the addition of MDCM hydrolysates of old laying hen might be useful from the point of view of improving unpopular meat consumption and reduction of livestock waste. However, occasionally these beneficial effects failed to show consistent trends during storage, and the exact mechanism for antioxidative, ACE-inhibitory, and liverprotecting activity of MDCM hydrolysates is not clearly understood. Therefore, further research is necessary to improve the bioavailability and to understand the exact mechanism of these hydrolysates.

\section{CONFLICT OF INTEREST}

We certify that there is no conflict of interest with any financial organization regarding the material discussed in the manuscript.

\section{ACKNOWLEDGMENTS}

This work was supported by Gyeongnam National University of Science and Technology Grant 2016.

\section{REFERENCES}

Ahhmed, M. A., S. Kawahara, and M. Muguruma. 2009. Transglutaminate improves the textural and structural properties of chicken skeletal, smooth, and cardiac muscles. In: Proceeding of the 55th International Congress of Meat Science and Technology. Copenhagen, Denmark.

Arihara, K., Y. Nakashima, T. Mukai, S. Ishikawa, and M. Itoh. 2001. Peptide inhibitors for angiotensin I-converting enzyme from enzymatic hydrolysates of porcine skeletal muscle proteins. Meat Sci. 57:319-324.

Battaller, R. and D. A. Brenner. 2005. Liver fibrosis. J. Clin. Invest. 115:209-218.

Bhaskar, N., V. K. Modi, K. Govindaraju, C. Radha, and R. G. Lalitha. 2007. Utilization of meat industry by products: protein hydrolysate from sheep visceral mass. Bioresour. Technol. 98:388-394.

Brand-Williams, W., M. E. Cuvelier, and C. Berest. 1995. Use of a free radical method to evaluate antioxidant activity. LWT-Food Sci. Technol. 28:25-30.

Chen, G. T., L. Zhao, L. Y. Zhao, T. Cong, and S. F. Bao. 2007. In vitro study on antioxidant activities of peanut protein hydrolysate. J. Sci. Food Agric. 87:357-362.

Dong, S., M. Zeng, D. Wang, Z. Liu, Y. Zhao, and H. Yang. 2008. Antioxidant and biochemical properties of protein hydrolysates prepared from Silver carp (Hypophthalmichthys molitrix). Food Chem. 107:1485-1493.

Escudero, E., M. A. Sentandreu, K. Arihara, and F. Toldrá. 2010. Angiotensin I-converting enzyme inhibitory peptides generated from in vivo gastrointestinal digestion of pork meat. J. Agric. Food Chem. 58:2895-2901.

Flaczyk, E., M. Rudzinska, E. Wasowicz, J. Korczak, and R. Amarowicz. 2006. Effect of cracklings hydrolysates on oxidative stability of pork meatballs fat. Food Res. Intl. 39:924-931.

Jang, A., C. Jo, K. S. Kang, and M. Lee. 2008. Antimicrobial and human cancer cell cytotoxic effect of synthetic angiotensinconverting enzyme (ACE) inhibitory peptides. Food Chem. 107:327-336.

Janitha, P. K., P. D. Wanasundara, A. R. S. Ross, R. Amarowicz, S. J. Ambrose, R. B. Pegg, and P. J. Shand. 2002. Peptides with angiotensin I-converting enzyme (ACE) inhibitory activity from defibrinated, hydrolyzed bovine plasma. J. Agric. Food Chem. 50:6981-6988.

Je, J. Y., P. J. Park, H. G. Byun, W. K. Jung, and S. W. Kim. 2005 a. Angiotensin I converting enzyme (ACE) inhibitory peptide 
derived from the sauce of fermented blue mussel, Mytilus edulis. Bioresour. Technol. 96:1624-1629.

Je, J. Y., P. J. Park, and S. K. Kim. 2005b. Antioxidant activity of a peptide isolated from Alaska pollack (Theragra chalcogramma) frame protein hydrolysate. Food Res. Int. 38:45-50.

Jin, S. K., I. S. Kim, Y. J. Choi, B. G. Kim, and S. J. Hur. 2010. Effect of surimi containing spent laying hen breast on the quality of crab analogue. J. Food Process Eng. 33:745-762.

Jin, S. K., I. S. Kim, H. J. Jung, D. H. Kim, Y. J. Choi, and S. J. Hur. 2007. The development of sausage including meat from spent laying hen surimi. Poult. Sci. 86:2676-2684.

Kaviarasan, S., N. Ramamurthy, P. V. Gunasekaran, E. Varalakshmi, and C. V. Anuradha. 2007. Epigallocatechin-3gallate(-) protects Chang liver cells against ethanol-induced cytotoxicity and apoptosis. Basic Clin. Pharmacol. Toxicol. 100:151-156.

Liu, Q., B. Kong, L. Jiang, X. Cui, and J. Liu. 2009 Free radical scavenging activity of porcine plasma protein hydrolysates determined by electron spin resonance spectrometer. LWTFood Sci. Technol. 42:956-962.

Liu, Q., B. Kong, G. Li, N. Liu, and X. Xia. 2011. Hepatoprotective and antioxidant effects of porcine plasma protein hydrolysates on carbon tetrachloride-induced liver damage in rats. Food Chem. Toxicol. 49:1316-1321.

Lee, S. J., E. K. Kim, J. W. Hwang, H. J. Oh, S. H. Cheong, S. H. Moon, B. T. Jeon, S. M. Lee, and P. J. Park. 2010. Purification and characterisation of an antioxidative peptide from enzymatic hydrolysates of duck processing by-products. Food Chem. 123:216-220.

Marklund, S. and G. Marklund. 2006. Involvement of the superoxide anion radical in the autoxidation of pyrogallol and a convenient assay for superoxide dismutase. Eur. J. Biochem. 47:469-474.

Moure, A., H. Dominguez, and J. C. Parajo. 2006. Antioxidant properties of ultrafiltration-recovered soy protein fractions from industrial effluents and their hydrolysates. Process Biochem. 41:447-456.
Pena-Ramos, E. A. and Y. L. Xiong. 2003. Whey and soy protein hydrolysates inhibit lipid oxidation in cooked pork patties. Meat Sci. 64:259-263.

Perna, A. F., D. Ingrosso, and N. G. De Santo. 2003. Homocysteine and oxidative stress. Amino Acids 25:409-417.

Qian, Z. J., W. K. Jung, and S. K. Kim. 2008. Free radical scavenging activity of a novel antioxidative peptide purified from hydrolysate of bullfrog skin, Rana catesbeiana Shaw. Bioresour. Technol. 99:1690-1698.

Rosen, G. M. and E. J. Rauckman. 1984. Spin trapping of superoxide and hydroxyl radicals. In: Methods in Enzymology (Ed. L. Packer). Academic Press, Orlando, FL, USA. 105:198209

Saiga, A., T. Okumura, T. Makihara, S. Katsuta, T. Shinizu, R. Yamada, and T. Nishimura. 2003. Angiotensin I-converting enzyme inhibitory peptides in a hydrolyzed chicken breast muscle extract. J. Agric. Food Chem. 51:1741-1745.

Sakanaka, S. and Y. Tachibana. 2006. Active oxygen scavenging activity of egg-yolk protein hydrolysates and their effects on lipid oxidation in beef and tuna homogenates. Food Chem. 95:243-249.

Siriangkanakun, S. and J. Yongsawatdigul. 2012. Trypsin inhibitory activity and gel-enhancing effect of sarcoplasmic proteins from common carp. J. Food Sci. 77:C1124-C1130.

Udenigwe, C. C. and A. Mohan. 2014. Mechanisms of food protein-derived antihypertensive peptides other than ACE inhibition. J. Funct. Foods. 8:45-52.

Udenigwe, C. C., H. Li, and R. E. Aluko. 2012. Quantitative structure-activity relationship modeling of renin-inhibiting dipeptides. Amino Acids 42:1379-1386.

Wu, H. C., H. M. Chen, and C. Y. Shiau. 2003. Free amino acids and peptides as related to antioxidant properties in protein hydrolysates of mackerel (Scomber austriasicus). Food Res. Int. 36:949-957.

Wu, K. C., Z. Y. Lin, S. H. Chiang, and C. Y. Chang. 2004. Antioxidant properties of porcine blood protein before and after enzymatic hydrolysis. J. Biomass Energ. Soc. China. 23:79-85. 